\title{
Malaria entomological inoculation rates in gold mining areas of Southern Venezuela
}

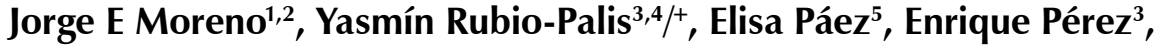 \\ Víctor Sánchez ${ }^{1}$, Elena Vaccari ${ }^{3}$ \\ ${ }^{1}$ Instituto de Altos Estudios en Salud Pública Dr. Arnoldo Gabaldon, Maracay, Venezuela ${ }^{2}$ Centro de Investigaciones de Campo Dr. Fran- \\ cesco Vitanza, Tumeremo, Bolívar, Venezuela ${ }^{3}$ Dirección de Control de Vectores, Ministerio del Poder Popular para la Salud, Maracay, \\ Venezuela ${ }^{4}$ BIOMED, Universidad de Carabobo, Maracay, Venezuela ${ }^{5}$ Servicio de Vigilancia Epidemiológica Sanitario Ambiental del \\ estado Bolívar, Cd. Bolivar, Venezuela
}

A longitudinal study of malaria vectors aiming to describe the intensity of transmission was carried out in five villages of Southern Venezuela between January 1999-April 2000. The man-biting, sporozoite and entomological inoculation rates (EIR) were calculated based on 121 all-night collections of anophelines landing on humans, CDC light traps and ultra violet up-draft traps. A total of 6,027 female mosquitoes representing seven species were collected. The most abundant species were Anopheles marajoara Galvão \& Damasceno (56.7\%) and Anopheles darlingi Root (33\%), which together accounted for $89.7 \%$ of the total anophelines collected. The mean biting rate for An. marajoara was 1.27 ( $S D \pm 0.81$ ); it was 0.74 ( $S D \pm 0.91$ ) for An. darling and 0.11 ( $S D \pm 0.10$ ) for Anopheles neomaculipalpus Curry and the overall biting rate was 2.29 (SD \pm 1.06$)$. A total of 5,886 mosquitoes collected by all three methods were assayed by ELISA and 28 pools, equivalent to 28 mosquitoes, yielded positive results for Plasmodium spp. CS protein. An. neomaculipalpus had the highest sporozoite rate $0.84 \%$ (3/356), followed by An. darlingi $0.82 \%$ $(16 / 1,948)$ and An. marajoara $0.27 \%(9 / 3,332)$. The overall sporozoite rate was $0.48 \%(28 / 5,886)$. The rates of infection by Plasmodium species in mosquitoes were 0.37\% $(22 / 5,886)$ for Plasmodium vivax (Grassi \& Feletti) and $0.10 \%(6 / 5,886)$ for Plasmodium falciparum (Welch). The estimated overall EIR for An. darling was 2.21 infective bites/person/year, 1.25 for An. marajoara and 0.34 for An. neomaculipalpus. The overall EIR was four infective bites/ person/year. The biting rate, the sporozoite rate and the EIR are too low to be indicators of the efficacy of control campaigns in this area.

Key words: man-biting rate - sporozoite rate - entomological inoculation rate - Anopheles - Plasmodium - Venezuela

The main foci of malaria in Venezuela are located south of the Orinoco River, particularly in state of Bolívar, where $87 \%$ of cases are reported and the municipality of Sifontes consistently reports Annual Parasite Indexes of 160-260 per 1,000 population (MS 2000-2007). The municipality of Sifontes has experienced tremendous ecological changes due to deforestation for mining, logging and urbanisation, with massive population movements from other parts of the country and abroad, which contributed to the increase in the reported number of malaria cases (INE 2001).

Longitudinal studies conducted in this area during the past decade have characterised the anopheline larval habitats (Moreno et al. 2000), species diversity (Moreno et al. 2002, 2004, Moreno \& Rubio-Palis 2003), anopheline

Financial support: Proyecto Control de Enfermedades Endémicas, Convenio Ministerio de Sanidad y Asistencia Social-Banco Mundial (VEN/96/002.021-023)

+ Corresponding author: rubiopalis@gmail.com

Received 16 March 2009

Accepted 4 June 2009 bionomics in relation to malaria transmission (Moreno et al. 2007) and vector incrimination (Moreno et al. 2005). Moreno et al. (2005) found Anopheles (Nyssorhynchus) darlingi Root, Anopheles (Nyssorhynchus) marajoara Galvão \& Damasceno and Anopheles (Anopheles) neomaculipalpus Curry that were positive for Plasmodium falciparum (Welch) and Plasmodium vivax (Grassi \& Feletti) variants 210 and 247 circumsporozoite (CS) protein. The presence of multiple vector species contributes to the complexity of malaria transmission in this area, where both $P$. falciparum and $P$. vivax are transmitted.

The entomological inoculation rate (EIR) estimates the risk of contracting malaria in a particular area by expressing the number of infective bites a person may receive per unit time (MacDonald 1957). It is the most important entomological parameter for assessing the level of malaria endemicity and the intensity of transmission in a given area (Rubio-Palis et al. 1992, Burkot \& Graves 1995). The EIR is highly valuable for monitoring the suitability of vector control operations (Coosemans et al. 1992) and the risk of development of an epidemic (Onori $\&$ Grab 1980). It is particularly relevant in areas with more than one species of vectors, such as the municipality of Sifontes, to estimate the contribution of each species to malaria transmission (Galardo et al. 2007). 
This research presents for the first time the EIR and its two components, the man-biting rate and the sporozoite rate, in the municipality of Sifontes.

\section{MATERIALS AND METHODS}

Study site - The study was conducted in five villages located in the municipality of Sifontes $\left(06^{\circ} 00^{\prime} 07^{\circ} 54^{\prime} \mathrm{N}\right.$, $\left.60^{\circ} 44^{\prime} 61^{\circ} 39^{\prime} \mathrm{W}\right)$, state of Bolívar, Southeastern Venezuela. The area and the villages have been previously described by Moreno et al. $(2002,2007)$. Transmission occurs throughout the year; the annual parasite index (API) was 813 cases per 1,000 population. Depending on the locality, the API varied from 71.6-2,492 per 1,000 population, with $P$. vivax accounting for $78.6 \%$ of the cases, $P$. falciparum for $21.4 \%$ and less than $0.1 \%$ being mixed infections $(P v+P f)$. Cross-sectional surveys conducted during the study showed that the prevalence varied from 12.5-21.4 cases per 1,000 population. More cases were diagnosed in the under- 15 age group than in any other group (Moreno et al. 2007). Vector control activities in this area includes house spraying with pyrethroids and space spraying with organophosphates in areas with active transmission, as well as selective treatment of larval habitats with Bacillus sphaericus.

Mosquito collections - Between January 1999-April 2000 , mosquito catches were carried out monthly during three consecutive nights in seven selected houses in each of the five villages, using three different collection methods simultaneously (Moreno et al. 2002). The first consisted of human landing catches from sunset to sunrise (18:30-06:30 h), indoors and outdoors, by a team of six catchers and one supervisor. Catchers worked in pairs for shifts of $4 \mathrm{~h}$, with one catcher indoors and the other about $3 \mathrm{~m}$ from the house; they rotated each night between indoor and outdoor shifts. For the second method, three CDC light traps were placed in three houses and run for $12 \mathrm{~h}$ (18:00-06:00 h). Finally, three up-draft ultra-violet traps (John W. Hock Co, Gainesville, FL) were placed in three houses and run during the same period as the CDC light traps. Moreno et al. (2002) found that three traps were equivalent to one human landing catch for both types of traps.

The functioning of traps was checked three times per night. Every night, the catching method used in each of the seven selected houses was rotated. The following morning, mosquitoes were identified using the keys of Cova García and Sutil (1977), Faran and Linthicum (1981) and Rubio-Palis (2000), counted and kept dry over silica gel for identification of Plasmodium spp. CS protein by ELISA.

Man-biting rate - The number of mosquitoes caught per day per person was estimated for the three commonest species caught in each village, considering all catching methods (a human landing catch is equivalent to three light trap catches) (Moreno et al. 2002).

ELISA procedure - The assays were performed at the Laboratorio de Ecología de Vectores, School of Malariology (now Instituto de Altos Estudios Dr. Arnoldo Gabaldon), Maracay. To reduce the probability of detection of Plasmodium spp. CS protein from other parts of the body (Rubio-Palis et al. 1992), only heads and thoraces were tested by ELISA for the CS protein of $P$. falciparum and P. vivax (polymorphs 210 and 247), following the standard protocols described by Moreno et al. (2005). Mosquitoes were tested in pools of less than 10 for each species, collection method and date, to ensure that the probability of detecting more than one infected mosquito per pool was less than 1\% (Rubio-Palis et al. 1992, Galardo et al. 2007, Magris et al. 2007).

Sporozoite rate and EIR - The number of CS-positive Plasmodium pools was equivalent to the number of CSpositive mosquitoes, so the sporozoite rate was estimated as the percentage of CS-positive mosquitoes divided by the total number of mosquitoes assayed. The annual EIR was estimated as the sporozoite rate multiplied by the man-biting rate, i.e., the mean number of female anopheline mosquitoes caught per night, multiplied by 365 .

Data analysis - To estimate the biting, sporozoite and EIRs, the numbers of mosquitoes collected were pooled by species over all the villages, collection nights $(n=$ 121) and trapping methods. To compare the observed differences in sporozoite rates between anopheline species, the confidence intervals were calculated according to the limits of expectations of binomial distributions (Drakeley et al. 2003). The program StatXact ${ }^{\circledR}$ (version 8: Cytel Inc 2007) was used for data analysis.

\section{RESULTS}

Anophelines abundance - A total of 6,027 female anopheline mosquitoes representing seven species were collected in all-night human landing catches $(3,725)$, CDC light traps $(1,349)$ and UV light traps (953). The most abundant species were An. marajoara $(56.7 \%)$ and $A n$. darlingi $(33 \%)$. The other species collected were An. neomaculipalpus $(\mathrm{n}=362)$, Anopheles braziliensis $(\mathrm{n}=103)$, Anopheles triannulatus $(\mathrm{n}$ $=42)$, Anopheles oswaldoi $(\mathrm{n}=12)$ and Anopheles apicimacula $(\mathrm{n}=1)$. The number of mosquitoes collected in each locality by species and by catching method has been reported previously (Moreno et al. 2002, 2007).

Man-biting rate - The number of mosquitoes collected in each locality was very low or zero for some species so, to estimate the biting rate, the numbers of mosquitoes collected were summed for all villages by species. The mean biting rate for An. marajoara was 1.27 ( $\mathrm{SD} \pm 0.81$ ); it was $0.74(\mathrm{SD} \pm 0.91)$ for An. darlingi and $0.112(\mathrm{SD} \pm$ 0.10 ) for An. neomaculipalpus (Table). The overall biting rate was $2.29(\mathrm{SD} \pm 1.06)$. In one year, a person might receive 463.6 bites from An. marajoara, 270 from An. darling and 41 from An. neomaculipalpus.

Sporozoite rate - A total of 5,886 mosquitoes, representing 684 pools, were assayed by ELISA (Table). Twenty-eight pools were positive for Plasmodium spp. CS protein. An. darlingi and An. marajoara were positive for $P$. vivax variants 247 and 210 and $P$. falciparum, while An. neomaculipalpus was found to be positive for both $P$. vivax variants for the first time in Venezuela (Moreno et al. 2005). An. neomaculipalpus had the highest sporozoite rate, $0.84 \%$ (3/356), followed by An. darlingi with $0.82 \%$ 


\section{TABLE}

Plasmodium falciparum, Plasmodium vivax 210 and P. vivax 247 circumsporozoite (CS) positive mosquitoes, man biting rate and entomological inoculation rate in anopheline species collected in five villages, municipality of Sifontes, state of Bolivar, Venezuela, January 1999-April 2000

\begin{tabular}{|c|c|c|c|c|c|c|c|c|c|}
\hline \multirow[b]{2}{*}{ Anopheles species } & \multirow[b]{2}{*}{$\mathrm{n}$} & \multicolumn{3}{|c|}{ Number positive for CS } & \multirow[b]{2}{*}{ Total } & \multirow{2}{*}{$\begin{array}{c}\text { Sporozoite rate } \\
\qquad(\%)^{a} \\
95 \% \mathrm{CI}^{b}\end{array}$} & \multirow{2}{*}{$\begin{array}{c}\text { Mosquitoes } \\
\text { caught } \\
n\end{array}$} & \multirow{2}{*}{$\begin{array}{l}\text { Biting } \\
\text { rate }^{c}\end{array}$} & \multirow[b]{2}{*}{$\mathrm{EIR}^{d}$} \\
\hline & & P. falciparum & P. vivax -210 & P. vivax -247 & & & & & \\
\hline An. darlingi & 1,948 & 4 & 11 & 1 & 16 & $\begin{array}{c}0.82 \\
(0.0047-0.013)\end{array}$ & 1,991 & 0.74 & 2.21 \\
\hline An. marajoara & 3,332 & 2 & 2 & 5 & 9 & $\begin{array}{c}0.27 \\
(0.0012-0.0051)\end{array}$ & 3,418 & 1.27 & 1.25 \\
\hline An. neomaculipalpus & 356 & 0 & 2 & 1 & 3 & $\begin{array}{c}0.84 \\
(0.0017-0.024)\end{array}$ & 362 & 0.112 & 0.34 \\
\hline Others $^{e}$ & 250 & 0 & 0 & 0 & 0 & $\begin{array}{c}0 \\
(0.000001-0.0146)\end{array}$ & 256 & 0.50 & 0 \\
\hline All species & 5,886 & 6 & 15 & 7 & 28 & $\begin{array}{c}0.48 \\
(0.0032-0.0069)\end{array}$ & 6,027 & 2.29 & 4.02 \\
\hline
\end{tabular}

$a$ : number of Plasmodium spp. CS protein positive mosquitoes divided by the total number of mosquitoes assayed; $b$ : the confidence intervals (CI) are calculated according to limits of expectations of binomial distributions (Drakeley et al. 2003); $c$ : mean caught per night by 2 human baits +3 CDC light traps +3 UV light traps (number of nights $=121$ ). Three light traps $=1$ human bait (Moreno et al. 2002); $d$ : biting rate x sporozoite rate x 365; e: other species, includes Anopheles braziliensis, Anopheles oswaldoi and Anopheles triannulatus; EIR: entomological inoculation rates.

$(16 / 1,948)$ and An. marajoara with $0.27 \%(9 / 3,332)$. Nevertheless, there is an overlap of the $95 \%$ confidence intervals based on the binomial distribution for these rates in different species, i.e., the rates do not differ significantly. The overall sporozoite rate was $0.48 \%(28 / 5,886)(95 \%$ $\mathrm{CI}=0.0032-0.0069)$. The rates of infection by Plasmodium species in mosquitoes were $0.37 \%(22 / 5,886)$ for $P$. vivax and $0.10 \%(6 / 5,886)$ for $P$. falciparum. In total, six mosquitoes $(21.4 \%)$ were positive for $P$. falciparum while $22(78.6 \%)$ were positive for P. vivax.

EIR - The number of infective bites a person might receive annually was 2.21 for An. darlingi, 1.25 for $A n$. marajoara and 0.34 for An. neomaculipalpus. The overall EIR was four infective bites per person per year.

\section{DISCUSSION}

The confirmed principal vectors of malaria parasites in the municipality of Sifontes are An. darlingi and An. marajoara, while An. neomaculipalpus is considered a secondary vector (Moreno et al. 2005).

The sporozoite rates reported in the present study for An. darlingi, An. marajoara and An. neomaculipalpus were less than $1 \%$. Similar results have been reported for An. darlingi in state of Amazonas (AM), Venezuela (Magris et al. 2007), Belize (Achee et al. 2000), French Guyana (Girod et al. 2008), Peru (FloresMendoza et al. 2004) and Rondônia (RO), Brazil (Soares Gil et al. 2003, 2007). So far, the highest sporozoite rates have been reported from other Brazilian Amazonian endemic areas, for An. darlingi $(2.1-8.5 \%)$ and Anopheles albitarsis s.l. (1.2 - 4.6\%) (Silva-Vasconcelos et al. 2002, Póvoa et al. 2006). An. marajoara (as An. albitarsis s.l.) has been previously incriminated in the transmission of malaria in Western Venezuela (RubioPalis et al. 1992, Rubio-Palis 1994) and in the states of São Paulo, Pará, Amapá (AP) and RO, in Brazil (Conn et al. 2002, Galardo et al. 2007). The infection rates reported in the present study confirm the importance of $A n$. darling $i$ as the principal malaria vector in the Amazon Basin (Zimmermann 1992, Lounibos \& Conn 2000, Rubio-Palis 2000) and in the southern foci of Venezuela, which include the states of Bolívar (Moreno et al. 2007) and AM (Magris et al. 2007) and also provided information about the role of An. marajoara as an emerging malaria vector in the region.

In the municipality of Sifontes, the reported biting rate for An. darlingi ( 0.74 bites/person/night) is considered extremely low in comparison to other studies. Nevertheless, low biting densities (5-10 bites/person/ night) seem to be characteristic of An. darlingi throughout its range of distribution (Roberts et al. 1987, Tadei et al. 1998, Soares et al. 2003, Brochero et al. 2005, Vittor et al. 2006). There are reports in Venezuela of biting rates that varied from 5.8-1,265 An. darlingi bites/person/night in different geographical areas (Rubio-Palis 1995, Magris et al. 2007, Moreno et al. 2007). In Brazil, Tadei and Dutary-Thatcher (2000) reported biting rates that varied from 0.13-53, whereas Galardo et al. (2007) reported much higher rates in AP, varying between villages from 53.9-837.7. The highest biting rate reported for An. darlingi in the Americas was 1,443 per night in Loreto, Peru (Calderón et al. 1995). An. marajoara was the most abundant species in the study area although its man-biting rate was only 1.27 bites/person/night (Table), which is lower than the biting rates (5.2-31.1) previously reported for this species in Western Venezuela (Rubio- 
Palis et al. 1992) and much lower than the rates (41.9316.2) reported in Brazil (Galardo et al. 2007). The overall biting rate in the study area is very low (2.29 bites/ person/night) (Table). It is important to point out that the abundance of mosquitoes in a particular area depends on the complex interactions of several factors such as rainfall, the river's water level and the availability of suitable larval habitats, among others (Charlwood 1996, Tadei et al. 1998, Magris et al. 2007, Moreno et al. 2007).

The EIR is the product of the sporozoite rate and the biting rate (WHO 1975) and describes the intensity of transmission (Burkot \& Graves 1995). The estimated EIR was 4.02 infective bites/person/year, i.e., a person in the study area might get one infective bite every three months. An. darlingi showed a higher EIR in the study area, with only 2.21 infective bites/person/year. Other studies in Venezuela have shown a much higher EIR. In fact, for the principal malaria vector in Western Venezuela, Anopheles nuneztovari, an EIR of 10.5 infective bites/person/year was reported (Rubio-Palis et al. 1992) whereas in the Upper Orinoco River, Magris et al. (2007) reported 129 infective bites/person/year for An. darlingi.

There are few studies in the Americas that have estimated the EIR of malaria-infected mosquitoes. Moreover, those studies were conducted mostly in the Brazilian Amazon and French Guyana; Soares Gil et al. (2003) reported an EIR of 10 infective bites/person/year for An. darlingi in RO, while in urban areas of Boa Vista, Silva-Vasconcelos et al. (2002) reported that the highest EIR was in An. albitarsis s.l. (6.9 infective bites/person/ year) and $A n$. darlingi only accounted for 1.65 positive bites/person/year. In the Upper Maroni area of French Guyana, the EIR for An. darlingi varied from 14.4-27.4 (Girod et al. 2008). Contrasting results were reported by Galardo et al. (2007) in three villages of AP, where the principal vectors are An. darlingi and An. marajoara and EIRs of over one infective bite/person/night were reported. These EIRs are the highest reported for the Americas and similar to those for Anopheles gambiae and Anopheles funestus in Africa (Hay et al. 2000). It is important to point out that the sporozoite rates reported by Galardo et al. (2007) for An. darlingi and An. marajoara are similar to the rates reported in the present study in the municipality of Sifontes. Nevertheless, the much higher EIRs reported in AP by Galardo et al. (2007) are due to the high densities of biting mosquitoes.

The present study confirms previous studies in which $A n$. darling $i$ was concluded to be the most efficient vector of malaria parasites in the Neotropical region, even at very low abundance (Rubio-Palis \& Zimmerman 1997, Lounibos \& Conn 2000, Póvoa et al. 2006).

The EIR reported here is in contrast to the high API (813 malaria cases x 1,000 population) and high prevalence of asymptomatic infections (27.6\%) observed during the study (Moreno et al. 2007). We have calculated a minimum estimate of the transmission efficiency of $P$. vivax and $P$. falciparum by dividing 0.813 cases per person per year by 4.02 infective bites/person/year; this suggests that $20.2 \%$ of bites from Plasmodium CS protein-positive mosquitoes result in infection in the munic- ipality of Sifontes. This efficiency is much higher than that estimated for P. vivax in Western Venezuela, where only $0.32 \%$ of infective bites infected a person (RubioPalis et al. 1992). On the other hand, the high incidence reported for the study area might also be due to failure to complete treatment and/or multiple drug resistance (Caraballo \& Rodríguez-Acosta 1999, Aché et al. 2002).

At present, the vector control program is based on indoors house spraying with pyrethroids, space spraying with organophosphate and larviciding with $B$. sphaericus in selected areas (MS 2008). The biting rate, sporozoite rate and EIR are so low that these parameters would not be a practical indicator of the efficacy of control campaigns in this area. The control of malaria in the municipality of Sifontes is complex due to its highly mobile population (Aché et al. 2002, Moreno et al. 2007), the circulation of P. falciparum strains with multidrug resistance (Caraballo \& Rodríguez-Acosta 1999, Aché et al. 2002), houses with incomplete or no walls in miners' camps and Amerindian villages and the outdoor biting and resting behavior of the principal vectors (Moreno et al. 2007). New approaches should be developed that take into consideration legislation on illegal mining, education, community participation and rapid diagnosis and effective treatment where monitoring of drug resistance is essential.

\section{ACKNOWLEGMENTS}

To Jeffrey Ryan, for providing the monoclonal antibodies for the ELISAs, to Luis Manuel Pérez, for helping with the statistical analysis, and to Chris Curtis, Bob Zimmerman and anonymous referees, for critics and suggestions.

\section{REFERENCES}

Aché A, Escorihuela M, Vivas E, Páez E, Miranda L, Matos A, Pérez W, Díaz O, Izarra E 2002. In vivo drug resistance of falciparum malaria in mining areas of Venezuela. Trop Med Int Health 7: $737-743$.

Achee NL, Korves CT, Bangs ML, Rejmánková E, Lege M, Curtin D, Lenares H, Alonzo Y, Andre RG, Roberts DR 2000. Plasmodium vivax polymorphs and Plasmodium falciparum circumsporozoite proteins in Anopheles (Diptera: Culicidae) from Belize, Central America. J Vector Ecol 25: 203-211.

Brochero HL, Rey G, Buitrago LS, Olano V 2005. Biting activity and breeding sites of Anopheles species in the municipality Villavicencio, Meta, Colombia. J Amer Mosq Control Assoc 21: $182-186$.

Burkot TR, Graves PM 1995. The value of vector-based estimates of malaria transmission. Ann Trop Med Parasitol 89: 125-134.

Calderón G, Fernández R, Valle J 1995. Especies de la fauna anofelina, su distribución y algunas consideraciones sobre su abundancia e infectividad en el Perú. Rev Peru Epidemiol 8: 5-23.

Caraballo A, Rodríguez-Acosta A 1999. Chemotherapy of malaria and resistance to antimalarial drugs in Guayana area, Venezuela. Am J Trop Med Hyg 61: 120-124.

Charlwood JD 1996. Biological variation in Anopheles darlingi Root. Mem Inst Oswaldo Cruz 91: 391-398.

Conn JA, Wilkerson RC, Segura MNO, De Souza RTL, Schlichting CD, Wirtz RA, Povoa MM 2002. Emergence of a new neotropical malaria vector facilitated by human migration and changes in land use. Am J Trop Med Hyg 66: 18-22. 
Coosemans M, Wery M, Mouchet J, Carnevale P 1992. Trasnmission factors in malaria epidemiology and control in África. Mem Inst Oswaldo Cruz 87: 385-391.

Cova García P, Sutil E 1975. Clave para adultos hembras de anofelinos de Venezuela. Bol Dir Malariol San Amb 15: 6-24.

Drakeley C, Schellenberg D, Kihonda J, Sousa CA, Arez AP, Lopes D, Lines J, Mshinda H, Lengeler C, Aemstrong Schellenberg A, Tanner M, Alonso P 2003. An estimation of the entomological inoculation rate for Ifakara: a semi-urban area in a region of intense malaria transmission in Tanzania. Trop Med Int Health 8: 767-774.

Faran ME, Linthicum KJ 1981. A handbook of the Amazonian species of Anopheles (Nyssorhynchus) (Diptera: Culicidae). Mosq Syst 13: 1-81.

Flores-Mendoza C, Fernández R, Escobedo-Vargas KS, Vela-Pérez Q, Schoeler GB 2004. Natural Plasmodium infections in Anopheles darlingi and Anopheles benarrochi (Diptera: Culicidae) from eastern Peru. J Med Entomol 41: 489-494.

Galardo AKR, Arruda M, D'Almeida Couto AAR, Wirtz RA, Lounibos LP, Zimmerman RH 2007. Malaria vector incrimination in three rural riverine villages in the Brazilian Amazon. Amer $J$ Trop Med Hyg 76: 461-469.

Girod R, Gaborit P, Carinci R, Issaly J, Fouque F 2008. Anopheles darlingi bionomics and transmission of Plasmodium falciparum, Plasmodium vivax and Plasmodium malariae in Amerindian villages of the Upper Maroni Amazonian Forest, French Guiana. Mem Inst Oswaldo Cruz 103: 702-710.

Hay SI, Rogers DJ, Toomer JF, Snow RW 2000. Annual Plasmodium falciparum entomological inoculation rates (EIR) across Africa: literature survey, internet access and review. Trans $R$ Soc Trop Med Hyg 94: 113-127.

INE - Instituto Nacional de Estadísticas 2001. Censo Oficial. Caracas, Venezuela. Available from: www.ine.gov.ve/demografica/ censopoblacionvivienda.asp.

Lounibos LP, Conn JE 2000. Malaria vector heterogeneity in South America. Am Entomol 46: 237-248.

MacDonald G 1957. The epidemiology and control of malaria, Oxford University Press, London, $120 \mathrm{pp}$.

Magris M, Rubio-Palis Y, Menares C, Villegas L 2007. Vector bionomics and malaria transmission in the Upper Orinoco River, Southern Venezuela. Mem Inst Oswaldo Cruz 102: 303-311.

Moreno J, Rubio-Palis Y 2003. Primer registro de Anopheles (Anopheles) costai y Anopheles (Anopheles) forattinii (Diptera: Culicidae) en Venezuela. Entomotrop 18: 211-213.

Moreno J, Rubio-Palis Y, Acevedo P 2000. Identificación de criaderos de anofelinos en un área endémica del estado Bolívar, Venezuela. Bol Dir Malariol San Amb 40: 21-30.

Moreno J, Rubio-Palis Y, Pérez E, Sánchez V, Paez E 2002. Evaluación de tres métodos de captura de anofelinos en un área endémica de malaria del estado Bolívar, Venezuela. Entomotrop 17: 157-165.

Moreno J, Rubio-Palis Y, Sánchez V, Mariany D 2004. Primer registro de Anopheles (Nyssorhynchus) nuneztovari Gabaldon, 1940 (Diptera: Culicidae) en el estado Bolívar, Venezuela y sus implicaciones eco-epidemiológicas. Entomotropica 19: 55-58.

Moreno JE, Rubio-Palis Y, Páez E, Pérez E, Sánchez V 2007. Abundance, biting behaviour and parous rate of anopheline mosquito species in relation to malaria incidence in gold-mining áreas of Southern Venezuela. Med Vet Entomol 21: 339-349.

Moreno JE, Rubio-Palis Y, Páez E, Pérez E, Sánchez V, Vaccari E 2005. Anopheles (Anopheles) neomaculipalpus: a new malaria vector in the Amazon Basin? Med Vet Entomol 19: 329-332.
MS - Ministerio de Salud 2007. Reportes Epidemiológicos, Semana 52. Dirección de Salud Ambiental, Maracay, Venezuela. Available from: www.mpps.gob.ve/ms/epidemiologia=malaria.

MS - Ministerio de Salud 2008. Boletín Informativo Semanal, Dirección de Control de Vectores, Reservorios y Fauna Nociva, Maracay, Venezuela. Available from: www.mpps.gob.ve/ms/ epidemiologia $=$ malaria.

Onori E, Grab B 1980. Indicators for the forecasting of malaria epidemics. Bull World Helth Org 58: 91-98.

Póvoa MM, Souza RTL, Lacerda NRL, Santa Rosa E, Galiza D, Souza JR, Wirtz RA, Schlichting CD, Conn JE 2006. The importance of Anopheles albitarsis $\mathrm{E}$ and Anopheles darlingi in human malaria transmission in Boa Vista, state of Roraima, Brazil. Mem Inst Oswaldo Cruz 101: 163-168.

Roberts DR, Alecrim WD, Tavares AM, Radke MG 1987. The housefrequenting, host-seeking and resting behavior of Anopheles darlingi in southeastern Amazonas, Brazil. J Amer Mosq Control Assoc 3: 433-441.

Rubio-Palis Y 1994. Variation of the vectorial capacity of some anophelines in Western Venezuela. Amer J Trop Med Hyg 50: 420-424.

Rubio-Palis Y 1995. Observaciones sobre el patrón de actividad hematofágica del vector de la malaria Anopheles darlingi en las poblaciones del sur de Venezuela. Bol Dir Malariol San Amb 35: 66-70.

Rubio-Palis Y 2000. Anopheles (Nyssorhynchus) de Venezuela: taxonomía, bionomía, ecología e importáncia médica, Escuela de Malariología y Saneamiento Ambiental Dr. Arnoldo Gabaldon, Proyecto Control de Enfermedades Endémicas, Maracay, 121 pp.

Rubio-Palis Y, Wirtz RA, Curtis CF 1992. Malaria entomological rates in Western Venezuela. Acta Trop 52: 167-174.

Rubio-Palis Y, Zimmerman RH 1997. Ecoregional classification of malaria vectors in the neotropics. J Med Entomol 34: 499-510.

Silva-Vasconcelos A, Neves Kato MY, Neves Mourão E, Lessa de Souza RT, Luz Lacerda RN, Sibajev A, Tsouris P, Povoa MM, Momen H, Rosa-Freitas MG 2002. Biting índices, host-seeking activity and natural infection rates of anopheline species in Boa Vista, Roraima, Brazil, from 1996-1998. Mem Inst Oswaldo Cruz 97: 151-161.

Soares Gil LH, Alves FP, Zieler H, Salcedo JMV, Durlacher RR, Cunha RPA, Tada MS, Camargo LMA, Camargo EP, PereiraDa-Silva LH 2003. Seasonal malaria transmission and variation of anopheline density in two distinct endemic areas in Brazilian Amazonia. J Med Entomol 40: 636-641.

Soares Gil LH, Tada MS, Katsuragawa TH, Ribolla PEM, PereiraDa-Silva LH 2007. Urban and suburban malaria in Rondônia (Brazilian Western Amazon) II. Perennial transmissions with high anopheline densities are associated with human environmental changes. Mem Inst Oswaldo Cruz 102: 271-276.

Tadei WP, Dutary-Thatcher B 2000. Malaria vectors in the Brazilian Amazon: Anopheles of the subgenus Nyssorhynchus. Rev Inst Med Trop Sao Paulo 42: 87-94.

Tadei WP, Dutary-Thatcher B, Santos JMM, Scarpassa VM, Rodrigues IB, Rafael MS 1998. Ecologic observations on anopheline vectors of malaria in the Brazilian Amazon. Am J Trop Med Hyg 59: 325-335.

Vittor AY, Gilman RH, Tielsch J, Glass G, Shields T, Lozano WS, PinedoCancino V, Patz JA 2006. The effect of deforestation on the humanbiting rate of Anopheles darlingi, the primary vector of falciparum malaria in the Peruvian Amazon. Am J Trop Med Hyg 74: 3-11.

WHO 1975. Manual on practical entomology, Parts I and II, WHO, Geneva, 191 pp.

Zimmerman RH 1992. Ecology of malaria vectors in the Americas and future directions. Mem Inst Oswaldo Cruz 87 (Suppl. III): 371-383. 